\title{
ANCIENT TECHNIQUES AND TRADITIONAL MEDICINE IN SUB-SAHARAN AFRICA : THE CASE OF FORGES OF OLD METALLURGY OF IRON
}

\author{
Mrs. KIENON-KABORE Timpoko Hélène, Lecturer, \\ tkienon@gmail.com \\ Faculty of Human and Society Sciences, University Félix Houphouët-Boigny, Côte d'Ivoire.
}

\begin{abstract}
.
In most traditional African societies, ancient techniques have played a vital role in the structuring of societies. Traditional farming techniques of iron, which have been the basis for several changes and transformation also had a real impact on the care of the patient. In a traditional environment, care concerns the soul before the physical body. Thus, divination, rituals, rituals are the sacrifices, amulets ports iron and other hardware precede or accompany body treatments. The body itself is treated when the soul finds its balance to avoid any recurrence. The blacksmith can then had the idea of plants, minerals, parts of living organisms such as animals, treat the visible physical illness. There is a link between matter, the environment and the body which explains the protocol set up by the blacksmith for the care of the sick which starts from the diagnosis to the tools of work in the traditional medicine. These treatment techniques can be addressed in multidisciplinary scientific research to understand the symbolism, gestures, rituals, hardware used to identify those that may assist in the management of patients with context culture is an important element in the diagnosis and care of evils .
\end{abstract}

Keywords - Techniques- metallurgy- iron- traditionnal medicine - Metallurgist - Smith.

\section{INTRODUCTION}

In Africa, technical practices often form a whole where rites, magic, gestures, words and signs combine to ensure a smooth operation, a good preservation of procedural secrets. The authors of these ancient techniques are often seen as separated beings who have close ties with the gods, they will be the ones that give power to extract often simple mate rials of nature, essential elements to companies. Iron is one of the elements of nature whose exploitation, from the search for ore to the obtaining of finished products, is surrounded by rites, symbolisms and practices, including the care of the sick. Thus, at the level of patient care techniques in the forge, rites and symbolisms are indissociable and form a set often complementary or sometimes ambivalent, thus conferring an enigmatical character to these jealously guarded practices in sub-Saharan African societies. Some aspects of these techniques are impenetrable by lay people because they are most often protected by prohibitions and secret practices. However, behind these often secretive and enigmatic practices lies a certain logic that researchers can penetrate to give a rational explanation in order to combine tradition and modernism. The trade of blacksmiths is a crucible of knowledge and know-how that is dying. What does old iron metallurgy represent in these societies ? What is the design of iron in these communities ? What are the symbolisms of blacksmith care?

To complete our reflection, we will discuss the subject in three points by taking examples in Côte d'Ivoire and Burkina Faso :

- Ancient Iron Metallurgy and Societies in Sub-Saharan Africa; ;

- The conception of iron in African societies: determining factor in the role of therapist of the actors;

- The blacksmith therapist: a privileged intermediary between the material and the immaterial.

\section{ANCIENT METALLURGY OF IRON AND SOCIETY IN SUB SAHARAN AFRICA}

2.1 An ancient industry of nearly 2500 years in Africa:

The practice of the old metallurgy of iron consists of a chain of operations which contains several stages. It includes the research and reduction of iron ore and the transformation of the magnifying glass into finished products. Iron metallurgy in Africa is an ancient industry of nearly 2500 years and has been essential in traditional 
African societies. $\left[{ }^{1}\right]$ In Burkina Faso the dates were obtained old. Some absolute dates give a chronology absolute which ranges between the V-VIth century and between XIth-XIIth century. In Côte d'Ivoire, research has uncovered a variety of technical traditions. The absolute chronology obtained by carbon dating 14 makes it possible to locate the production of the old metallurgy of iron between the 10th and the 19th century. $\left[^{2}\right]$ They confirm the age of metallurgy in these societies. The work of iron metallurgy differs from one society to another in sub-Saharan Africa, hence the wealth of processes, techniques and symbolism. But the common point or calf craft metalworker, smith is the essential role of the actors of these ancient techniques.

\subsection{Metallurgists and blacksmiths :}

At the operational chain of ancient iron metallurgy, there's metallurgists and blacksmiths who can play roles differents according to the companies. In some African societies, the stages of the operating chain s have done the same actors that extract and nt converts ore reduction furnaces and e deal later in the forge. They are identified by the term blacksmith. This is the case of the blacksmiths of a large part of the blacksmith society of Burkina Faso. $\left.{ }^{3}\right]$ In other societies, however, metallurgists and blacksmiths are distinct. Those who extract iron ore and reduce iron ore in furnaces are different from blacksmiths who work in the forge for making finished objects. They are called respectively : metallurgists and blacksmiths. $\left[{ }^{4}\right]$ In our approach, the term blacksmith refers to both the metallurgist and the blacksmith.

\subsection{The blacksmith : a key player in society :}

The blacksmith in the traditional society in Africa is not only the one who produces the iron. He is also the one who ensures the survival of the community by making the tools of rural work. It is thanks to its knowledge and its proximity to the Gods that society feeds itself, defends itself, heals itself and assures different societal needs. In the Bulkiemdé province, its role is very socially determined.

The blacksmith, a central figure in society, is at the beginning and end of life. In fact, he treats infertile women, also gives birth to those who are dysocic, and provides material and cult support for the burial of the individuals of all the inhabitants of the village.

The blacksmith in this society becomes a key figure. He heals the body and the spirit, protects and advises. Indeed, $\mathrm{He}$ is a therapist, solicited for the care of children and adults. He treats hemorrhoids, sterile women, makes bracelets and amulets for the protection of body and mind etc. The blacksmith thus concludes a pact between the families he protects and the gods of the forge responsible for maintaining a certain social peace by punishing offenders to the laws of society (kill in witchcraft, poison or cast a spell ...). The blacksmith is also asked for his mediating role in conflicts. His intervention, voluntary or at the request of the villagers, in case of conflict, serious quarrels in families, attempted suicide is considered sacred and should not be refused. The rejection of forgiveness entails serious penalties from the blacksmith gods and blacksmiths themselves who may prohibit the donation or sale of iron objects to the person or community concerned.

In families, he is also responsible for announcing deaths. By its action it soothes pain and prevents sensitive souls from hurting themselves. A person caught in the act of suicide is invited not to do it again, otherwise he will not benefit from purifying rites of blacksmiths before burial, nor iron instruments needed to dig his grave. He is also considered the privileged mediator between the things of the earth, the living beings and the Gods of lightning, all the more so because he is the master of fire.As a result, he is the only one allowed to purify the bodies of humans and animals killed by lightning. .

$\left[{ }^{1}\right]$ BOCOUM H. (under the direction of) : Aux origines de la métallurgie du fer en Afrique. UNESCO, Paris, p 35, (2002).

[2] SERNEELS V., KIENON-KABORE T.H., KOTE L., KOUASSI S.K., MAUVILLY M., RAMSEYER D., SIMPORE L., Origine et développement de la métallurgie du fer au Burkina Faso et en Côte d'Ivoire. Premier résultats sur le site sidérurgique de Siola. (Kaniasso, Denguélé, Côte d'Ivoire). Journal de la fondation Suisse-Liechtenstein pour les recherches archéologiques à l'étranger, SLSA, p 113. (2013).

[3 ] KIENON-KABORE T. H. : La métallurgie ancienne du fer au Burkina Faso : province du Bulkiemdé. Approche ethnologique, historique, archéologique et métallographique. Un apport à l'histoire des techniques métallurgiques en Afrique. Ed l'Harmattan, p101, (2003).

[ $\left.{ }^{4}\right]$ COULIBALY E. : Savoirs et savoir-faire des anciens métallurgistes d'Afrique occidentale : procédés et techniques de la sidérurgie directe dans le Bwamu (Burkina Faso et Mali). Ed Karthala, (2006). 
Its object of pacification is the anvil. It constitutes the central element of the forge at the level of technique and worship. At each dispute settlement, the blacksmith throws it between the belligerents who are no longer allowed to step over the object of worship to continue the conflict. The blacksmith is also the only one to be able to make objects of worship in iron for the Nyonyosos (the iron ax) and the Sikoms (mask bearers) who need an iron instrument to realize their mask. These vital functions for society make the blacksmith a must and soughtafter at all levels of society. The design of iron ore and the iron element in these societies also contributes to the society's vision of the blacksmith and its function as a therapist.

\section{THE CONCEPTION OF IRON IN AFRICAN SOCIETIES : DETERMINING FACTOR IN THE FUNCTION OF THERAPIST OF ACTORS}

\subsection{Iron: Being alive or God civilizing}

The iron is a living / God or God civilizing different societies. One of the convergence points of the spirituality of African societies lies in the belief in a Supreme Being who creates and governs the entire Universe, a strictly ordered space. The balance of society and individual guarantors of social and individual well- being at the physical and moral level is linked to the proper arrangement of this universe. Iron is an element of this universe directly related to the supreme God or itself constituting a civilizing God in many African societies. In the Yoruba society we have the God of iron, blacksmiths and the war that is called OGUN. The Fon in Togo, Benin and Ghana have a God who is the GU in metals. The Dogon of Mali names this supreme deity Amma. The century blacksmiths companies in Burkina Faso are calling for Bamogo ancestor founder. As for the Senufo in Côte d'Ivoire, the Koltchôr is the supreme being who rules the world of blacksmith's.

\subsection{The old iron metallurgy and the physical and social balance of the individual and the group}

Iron being a deity related to fire and elements of the natural environment, it can have positive consequences or Negatives on the human level community and Individual.

At the community level, iron being linked to the deity of fire and nature, it must be treated with great respect. In the opposite case, the community may be afflicted with diseases or misfortunes of all kinds. Different causes are cited for expliq s uenceare the evils that often target the whole community.

Failure banned during the production of iron is often the first cause of ailments. The transgression of sexual erdits int at the exploitation of iron, from the extraction of iron ore to the production of finished objects to the forge, is the majority of the causes of the imbalance between the human and the environment. In a word, these taboos are moral p rinciples governing companies. It is the fight against adultery, immoral sexual practices and the maintenance of good social cohesion in the blacksmith community [ $[5]$

The bad practice of rituals and rites (sacrifice of animals, and magico-religious practices) during the prospection, the extraction of iron ore at the mine and the reduction of the iron ore in the furnaces is also a cause the imbalance between the human and his environment. Indeed, the chain of operations of the old iron metallurgy is accompanied by magical religious practices and animal sacrifices for the smooth running of operations and peace for the communities involved. Failure of these forbidden magical and religious practices can lead $\mathrm{ubad}$ campaign of the production of iron, $\mathrm{u} n$ landslide at the mine during the extraction of the ore, are of serious diseases and misfortunes at Community level. According to traditionalists and blacksmiths, the Failure to comply with these rules entails indeed the imbalance between the visible and invisible physical matter. The Corps is achieved because the balance between human body, vegetable or mineral environment and the invisible (the world of the Gods, Geniuses and spirits etc.) is not respected. $\left.{ }^{6}\right]$ At the individual level the causes of disease are often the same as those of Community disease except that the disease only affects the community member who has violated the rules of life at the practice of the profession and also at the societal level.

The blacksmith who is the intermediary between Gods and humans is one of those who are empowered to restore balance through practices and attitudes peculiar to this corporation. Thus he is responsible and assumes several functions.

[5] Kiendrébéogo Kudu information on ancient iron metallurgy in Bulkiemd ed, Burkina Faso, (1988).

[6] Coulibaly Adama, information on the old iron metallurgy at Doumbala in Folon, Côte d'Ivoire, (2015). 


\section{THE FORGERON THERAPIST: A PRIVILEGED INTERMEDIATE BETWEEN MATERIAL AND INTANGER}

The blacksmith, by his functions and by the community's conception of him, becomes a central figure in societal life. He is the privileged intermediary between humans and Gods. He diagnoses the ills of his patients by different methods and cares for them in his forge which is a sanctuary, or outside his place of work by giving potions and amulets of metals and other secret practices.

\subsection{The diagnosis of disease in the blacksmith therapist}

Given the vision of iron and blacksmith in society, the diagnosis of disease is often linked to these conceptions. Disease is the first of all the fact of invisible forces that must be detected. He thus proceeds by direct observation of the patient, by divination in the blacksmith or by another diviner, by incantations and magicoreligious formulas to know the origin of the evil and also by observation of the flora and fauna environment or by traces left by them. Indeed, according to the blacksmiths, the observation of the nature, the fauna and the flora often gives important information on the state of health of the patient and can give essential elements on the future and the sacrifices to make before to begin the care of the physical body. Visible nature is a reflection of invisible events. $\left[{ }^{7}\right]$

\subsection{Disease prevention}

The blacksmith also heals and prevents disease of body and mind by using amulets, rings and bracelets made rious themselves and soaked in various concoctions. Elements of the forge are also used for preventions. They use different metalsaccording to the nature of the evil. The forms of open or closed bracelets represent a certain symbolism. The using-shaped s s zoomorphic or anthropomorphic bracelet and other amulets are made according to the deity s, the benevolent spirits and other elements of nature that protects and ensure the balance of mind and body.

The blacksmith uses the implanted anvil as a rotational force. Indeed, the anvil is the central element at the technical and religious level. It is on the anvil that are made tools and other elements necessary to society. It is also the basic element on which the various rituals related to the forge are performed. The forge, blacksmith shop is not only a magnifying glass processing place into finished products, where rituals are made for the worship of the Gods, to expiate certain faults, to protect families, to cure patients, to make vows etc. At the level of the province of Bulkiemde, the opening of the trade of blacksmith to engender on the social and religious level, types of forges sanctuaries. Indeed, unlike the blacksmiths ofYatenga in northern Burkina Faso where blacksmiths are in a system of endogamy, those of Bulkiemdé have an open system. They contract marriages with other members of the community. In these societies, one becomes a blacksmith. That is, blacksmiths of origin can train and pass on their knowledge to non-blacksmiths. This opening of the blacksmith trade has favored the existence of other types of forges implanted in non-blacksmith families. On these shrines, we do not transform the magnifying glass into finished products. They consist only of anvils on which families can sometimes spare iron tools. The essential function of these sanctuary forges is to protect the family from diseases and evil spirits. The establishment of these forges is advised by diviners who indicate the village where the head of the family must go to seek his forge, for the protection of his own. A single family may have several protective forges of various origins. The owners are not considered blacksmiths.

\subsection{Symbols and techniques of care at the blacksmith}

The symbolism of care manifests itself on several levels. For our approach we will give examples of iron ore, reduction furnace and smithy.

In iron ore, different types of iron ore are used in skin care and for the protection of the body and mind. According to their nature, the minerals that are living beings, Gods, intermediate between the supreme God and humans, contain supernatural powers that heal and protect. In the reduction of iron ore, the furnace, the accessories and the products of the reduction, such as magnifying glass and iron slag, constitute products of care and protection. The reduction in the symbolism of the blacksmith represents a woman in labor to give birth to her child. The using terracotta furnace body for care dystocic women reflects this symbolism. Dare iron slag, remained in the base of the furnace are used in the care of skin diseases, the last block of magnifying glass for anti- bullet amulets and other mystical preparations. The difficulties of obtaining the magnifying glass of

\footnotetext{
${ }^{7}$ Bamba Bakary, information on the ancient iron metallurgy, Siola, Folon, Côte d'Ivoire, (2014).
} 
iron is the symbolism which explains in part its use for the making of anti-bullet amulets. $\left[^{8}\right]$ The plants that grow in the center of furnace cooked by fire and abandoned s are used for treatment of serious diseases s whose origin is considered as mystic. For blacksmiths, it is rare for plants to grow in the center of the reduction furnaces that are cooked by the fire of reduction. The blacksmith therapist considers that if a plant manages to grow under these conditions, it has a relationship with nature that is not ordinary and can serve to unravel what is so mysterious and difficult to undo in the visible world. At the level of the forge, where the iron is transformed into a finished product, the space of the forge consisting of the hearth, the bellows and the anvil constitutes in itself a positive energy for the care of the body and the body. 'mind.According to the blacksmiths, all the symbolism of the creation of the universe is there and constitutes a holy space for all visible and invisible entities. So, people can often stay at the forge for a while to be followed spiritually. For all these reasons, the forge is the place where s the sacrifice for the care and protection are. The blacksmith prepares his potions for care and protection. He makes it all the iron objects are for the care, protection and enhancement of the mystic power of some Scorporation as hunters, warriors etc. The sand where the anvil is implanted, the water used to make the finished objects by soaking, the scales of the forge and the ashes are used for the care of diseases whose origin is considered as mystical.

It must be known that all this symbolism is based on cultural ideas created in society. In the imaginary universe of artisans and metallurgists, everything that is part of the cosmos is alive and has a soul and secrets as a human. Ain so if iron is a wonder metal. He is a living being, to whom he must be attentive in order not to offend him at the risk of being punished or failing the technical operation. It has significant harmful power that can be exerted on blacksmiths, metallurgists as well as their families over several generations. Hence the practice of sacrificial rituals at each technical stage of the chain of operations of the direct steel industry. This character's my tick and secrecy surrounding the raw material of work has two profound meanings: the first is religious because it allows artisans to stay in touch with their gods while showing the importance of these in their activity, second which is my s tick allows to put an opacity in these technical facts. Thus the laymen are kept apart and the apprentices who want to understand will seek to unravel the mystery necessary for the technical exchange. Thus the blacksmith out of his imagination cultural elements that allow him to protect himself as well as his profession of the world profane and initiated. The anthropomorphization of the raw material can be explained by the symbolization of the operating chain which gives the magnifying glass whose fundamental principles are not always known to them. For the latter and also for the layman, the metallurgist extracts the metal from simple pebbles that give the rare, precious and sought-after iron in society. They fight against the fire my mystical element in the cosmogony in Black Africa. In the collective imagination of the blacksmiths and metallurgists, the extraction of the ore which is a living being constitutes the gestation, the reduction in the "belly of the furnace" as they designate it to the North of Côte d'Ivoire in the region from Korhogo and Odienné, represents the working term woman whose magnifying glass symbolizes childbirth. $\left[{ }^{9}\right]$ The organization of iron ore reduction areas in some metalworking communities also responded to an imaginary world in which symbolism and technique combine to bring harmony to the operation. The imaginary will play its role in the location of the site and the arrangement of the stoves. Georges Celis in his book on African foundries, quotes three types of furnace layout, online (Niger and Côte d'Ivoire)), grouped (Côte d'Ivoire) and circle (Niger). For him this was a response to a search for time and profitability. $\left[{ }^{10}\right]$ In the region of Korhogo and in dd'Odienné area north of the Ivory Coast, thre types of reducing the space organization were discovered on various steel plants. The online layout could go up to 30 furnaces aligned on the North-South axis. The embrasures and doors respectively on the East and West side. Some blacksmiths in the area who attributed the sites to their ancestors justified the organization of the reduction area by the importance of the four cardinal points in the success of the reduction operation. In their imagination, East and West symbolize the entrance and exit of the world through the sunrise and sunset. The embrasures and doors play an important role in the operation of the furnace for the slag removal, the recovery of the magnifying glass and should be located in the East and West to ensure the success of the reduction according to the metallurgists. The reduction of iron ore by natural draw was made in this part of Africa between the months of December and January when the winds of the harmattan blow at this time of the year. The direction of the wind plays a lot in the orientation of the furnaces. When asked about the utility of the wind in furnace orientation, metallurgists confirm their importance in the organization of the reduction space. $\left[{ }^{11}\right]$

$\left.{ }^{8}\right]$ Bamba Bakary, information on the ancient iron metallurgy, Siola, Folon, Côte d'Ivoire (2014).

$\left[{ }^{9}\right]$ KIENON-KABORE T.H., Imagination and ancient techniques in sub-saharanafrica. European Journal of Research in Social Sciences, Volume 5, Number 5, p 46, (2017)

$\left[{ }^{10}\right]$ CELIS G., Les fonderies africaines. Frankfurt am Main, p 102, (1991)

$\left[{ }^{11}\right]$ ] KIENON-KABORE T.H., Imagination and ancient techniques in sub-saharanafrica. European Journal of Research in Social Sciences, Volume 5, Number 5, p 46, (2017) 
The activities of blacksmiths are often surrounded by symbolisms that are based on the visible and invisible world. The blacksmith's techniques of care are first immaterial before being material. For this approach we have presented data that shows the omnipresence of symbolism. The research we are conducting in the perspectives will attempt to understand the real technical logic in the blacksmiths' practices in order to derive what can be scientifically proven and usable in our modern approaches.

\section{Conclusion}

Research shows the connection between matter, the environment and the invisible in traditional medicine. It is a reflection of culture, technical thoughts, religious and screw i on the world in which live actors. Researchers are most often in phase with this culture they must understand. In this, the social sciences, namely anthropology, sociology, history, archeology and pharmaceutical sciences, biological, medicinal should work for interdisciplinary study's for a more effective approach to traditional medicine. The study of these traditional techniques is urgent because of the loss of information. Indeed, resource persons disappear and these ancestral practices are most often rejected and relegated to the background. In recent years, research is being put in place and helps safeguard some of the heritage of traditional medicine that needs a more committed policy of African states.

\section{1- ORAL SOURCES}

\begin{tabular}{|c|c|c|c|c|}
\hline LAST NAME FIRST NAME & $\begin{array}{l}\text { OCCUPATION / } \\
\text { STATUS }\end{array}$ & AGE & LOCALITY OF THE SURVEY & $\begin{array}{l}\text { DATE OF THE } \\
\text { SURVEY }\end{array}$ \\
\hline KIENDREBEOGO Kudu & $\begin{array}{l}\text { Old blacksmith } \\
\text { Farmer }\end{array}$ & $\begin{array}{l}108 \text { years } \\
+1996\end{array}$ & Tiogo (Burkina Faso) & $\begin{array}{l}27.09 .1988 \\
09.28 .1988 \\
23.12 .1988 \\
25.12 .1988 \\
01.26 .1991 \\
22.12 .95\end{array}$ \\
\hline $\begin{array}{l}\text { KIENDREBEOGONoaga a } \\
\text { nd his sons }\end{array}$ & Old blacksmith & 70 years & $\begin{array}{l}\text { Doulou } \\
\text { (Burkina Faso) }\end{array}$ & Sept. 1994 \\
\hline BAMBA beri & $\begin{array}{l}\text { Cultivator and } \\
\text { blacksmith }\end{array}$ & 69 years & Sangouani (Ivory Coast) & 30.04 .2014 \\
\hline BAMBA Bakary & $\begin{array}{l}\text { Cultivator and } \\
\text { blacksmith }\end{array}$ & 60 years & Siola (Ivory Coast) & 04.30 .2014 \\
\hline Coulibaly Adama & Farmer & 65 years & Doumbala (Ivory Coast) & 02.15 .2015 \\
\hline KIENDEBEOGO Règma & Old blacksmith & $\begin{array}{l}60 \text { years } \\
+1994\end{array}$ & Tiogo (Burkina Faso) & Sept.1988 \\
\hline KIENON Yembi & $\begin{array}{l}\text { Mask carrier } \\
\text { Farmer }\end{array}$ & $\begin{array}{l}53 \text { years } \\
1994\end{array}$ & Tiogo (Burkina Faso) & $\begin{array}{l}22.12 .1988 \\
03.01 .1990\end{array}$ \\
\hline KINDA Olivier & Old blacksmith & $\begin{array}{l}105 \text { years } \\
+1995\end{array}$ & Réo (Burkina-Faso) & $\begin{array}{l}\text { 23.12.1988 } \\
\text { August } 1993\end{array}$ \\
\hline
\end{tabular}




\begin{tabular}{|l|l|l|l|l|}
\hline & & & & 01.11 .94 \\
\hline $\begin{array}{l}\text { NIKIEMAKomênêmmoog } \\
\text { O }\end{array}$ & Black-smith & 65 years & Ralo (Burkina-Faso) & $\begin{array}{l}22.12 .1988 \\
09.11 .1989 \\
29.11 .1989\end{array}$ \\
\hline $\begin{array}{l}\text { OUIKIEMA Wogo } \\
\text { Souleymane }\end{array}$ & Black-smith & 85 years & Poa ( Loaga )Burkina Faso & 25.01 .1990 \\
\hline ZONGO Bangba & Farmer, hunter & & Nawavogo (Ivory Coast) & 17 to 20. 072011 \\
& & & & 11 to 15.3. \\
& & & & 2014 \\
\hline ZONGO konyib & Black-smith & 60 years & Nandjèla & 25.08 .1994 \\
& & & & 20.09 .1994 \\
& & & & 30.08 .1993 \\
\hline
\end{tabular}

\section{2-BIBLIOGRAPHY}

[1] BOCOUM H. (under the direction of) : Aux origines de la métallurgie du fer en Afrique. UNESCO, Paris

[2] CELIS G., Les fonderies africaines. Frankfurt am Main, 223p. (1991)

[3] COULIBALY E. Savoirs et savoir-faire des anciens métallurgistes d'Afrique occidentale : procédés et techniques de la sidérurgie directe dans le Bwamu (Burkina Faso et Mali). Ed Karthala, 422p (2006)

[4] GALlay A., HUYSECOM, E. et MAYOR A., Peuples et céramiques du Delta intérieur du Niger (Mali). Terra archaeologica III. Mainz: von Zabern (1998).

[5] GARCON A.F, L'imaginaire et la pensée technique. Une approche historique XVIe-XXe siècle. Classique Garnier, Paris, 286p. (2012)

[6] GARCON A.F., Les techniques et l'imaginaire. Hypothèse, pp.221-228 (2005)

[7] KIENON-KABORE T.H., History of traditional science and technology in subsaharan africa: problematic and methodology of approach. International Journal of Academic Research and Reflection, Volume 5 Number 5, pp 47-59. (2017)

[8] KIENON-KABORE T.H., Imagination and ancient techniques in sub-saharanafrica. European Journal of Research in Social Sciences, Volume 5, Number 5, pp42-53 (2017)

[9] KIENON-KABORE T.H., La sidérurgie directe en Côte d'Ivoire : Contexte et résultats de la recherche. European Scientific Journal, October, 2012, Vol(8) N²3, pp 144-161. (2012)

[10] KIENON-KABORE T.H. La métallurgie ancienne du fer au Burkina Faso : province du Bulkiemdé. Approche ethnologique, historique, archéologique et métallographique. Un apport à l'histoire des techniques métallurgiques en Afrique. Ed l'Harmattan, 328p. (2003)

[11] KIETHEGA J.B. La métallurgie lourde du fer au Burkina-Faso. Une technologie à l'époque précoloniale. Ed Karthala, 500p. (2009)

[12] MARTINELLI, B., La mémoire en travail - A propos de la forge au Burkina Faso, in Les territoires du travail - Mémoires en Actes, CATEIS, 1 pp 65-76. (1998)

[13] MAYOR. A., Outils de potières au Mali : chaînes opératoires et traditions techniques. In : Y. Maigrot et J. Vieugue (dir.), Outils de potier néolithiques : traditions techniques et organisation des productions céramiques. Actes des séances de la Société Préhistorique Française, 17 mars 2010, Nanterre, Bulletin de la société préhistorique française 107/4, 643666), (2010). 
[14] SERNEELS V., KIENON-KABORE T.H., KOTE L., KOUASSI S.K., MAUVILLY M., RAMSEYER D., SIMPORE L., Origine et développement de la métallurgie du fer au Burkina Faso et en Côte d'Ivoire. Premier résultats sur le site sidérurgique de Siola. (Kaniasso, Denguélé, Côte d'Ivoire). Journal de la fondation SuisseLiechtenstein pour les recherches archéologiques à l'étranger, SLSA, pp 113-143. (2013).

[15] THIOMBIANO-ILBOUDO, F.E., Les vestiges de l'occupation Humaine ancienne dans la province du Gourma. Des origines à la pénétration coloniale. (Cas de Kouaré et de Namoungou). Thèse de Doctorat Unique, Université de Ouagadougou, Burkina Faso, 664 p. (2010). 